\title{
Clinical evaluation of an Ayurvedic Formulation in the management of Avaranajanya Madhumeha (Type 2 Diabetes Mellitus)
}

\author{
DEVASHISH BHARDWAJ, VEENIT K. AGNIHOTRI and PRANAV PANDYA
}

\begin{abstract}
A research plan has been developed in the present study to address the problems associated with $i \quad$ (type 2 diabetes). This research plan is based on the treatment methods of Ayurveda (ancient Indian medicine) and utilization of modern scientific methods as research tools. A specific ayurvedic herbo-mineral formulation has been prepared in Ghansatt (solid extract) form; the selected eight herbs and one herbo-mineral have anti-hyperglycemic (PRAMEHA HARA) and antihypercholestermic (MEDOHARA) properties with rejuvenative (RASAYANA) effects as described in classical ayurvedic methods. 15 diagnosed type II diabetes mellitus patients were selected through accidental sampling. Ayurvedic formulation was prescribed to type II diabetes patients for one year along with dietary restrictions. Diabetic diagnostic parameters of these patients like Fasting Blood Sugar (FBS), Post Patrum Blood Sugar (PPBS), Glycocylated Hemoglobin (HbA1C) and Urine Sugar Fasting were monitored every three months; these were measured before and after intervention. The obtained data were statistically analyzed through paired t-test. There was significant reduction in FBS level, PPBS level, HbA1C level and urine fasting sugar level in type 2 diabetes patients who completed the clinical trial successfully. Thus, ayurvedic formulation treatment lead to an overall significant reduction in blood sugar and urine sugar levels in type II diabetes patients. No side effects were noted during the study period. This study suggests that the had very good hypoglycemic effects proved by clinical improvement and bio-chemical analysis of diabetes parameters in the treatment of type II diabetes mellitus.
\end{abstract}

$\begin{array}{llll}g & V & \text {, Type II diabetes mellitus, } & \text { Blood glucose. }\end{array}$

$i \quad H$ diabetes has mentioned that in $i$, the vitiated mellitus) is a disease, which has plagued man for remain in the lower part of the body owing centuries, especially in the more developed areas to the inefficiency of various , i.e. of the world. It is considered one of the five vessels (Shastri, 1995). $i$ was declared leading causes of death in the world and an important human ailment afflicting people from various walks of life in different countries. In India, it is proving to be a major health problem, especially in the urban areas.

In this disease, polyuria and honey urine was noted as early as $400 \mathrm{BC}$ by the Indian Physician He has described this disease as ' $i \quad$ WWhich means honey in the urine (Sharma, 1983). $\quad o \quad$ (Nidana, 6/27) (difficult to treat) and even (incurable) by ancient . They have explained that all types of (diabetes), if left or partially treated, convert into (difficult to treat diabetes, i.e. type 2 diabetes mellitus - T2DM) (Ch.Su.17/80); and later on, if not treated properly, a period comes when it converts to (incurable diabetes, i.e. type 1 diabetes mellitus - T1DM) (Sharma, 2001). 
It is still a challenge for every system of medicine to treat this disease. It has turned out to be the biggest "silent killer" today in the world. Type I Diabetes Mellitus (T1DM) is nearer to $i \quad H$ while Type II

$\begin{array}{cccc}\text { Diabetes } & \text { Mellitus } & (\mathrm{T} 2 \mathrm{DM}) & \text { resembles } \\ & i & J & \end{array}$

In

$i$

(phlegm

or water element) is the predominant (humour) while the important

(affected tissues) are (fat) and (fluid of the body). channels of htismours) pathogenesis occurs due to etiological factors mainly concordant with (water element) and (fire element), but the vitiation of (air element) occurs due to (blockade of the channels). Patients are (obese) and considered to be

This is equivalent to T2DM (also called noninsulin-dependent diabetes mellitus - NIDDM), which is mainly associated with 2002). (pathogenesis) (Shukla \& Tripathi,

Diabetes Mellitus (DM) is defined as a disturbance of intermediary metabolism, manifesting as a chronic sustained hyperglycemia primarily due to either an absolute or relative lack of insulin. It appears to be prevalent at "epidemic" levels in many countries of the world. T2DM is one of the most severe metabolic pandemic of the 21 st century, affecting essential biochemical activities in almost every cell in the body and increasing the risk of cardiac problems. It is estimated that in the year 2000, 171 million people had diabetes, and this is expected to double by year 2030 (Boon $\quad$ H006). The global prevalence of diabetes is estimated to increase, from $4 \%$ in 1995 to $5.4 \%$ by the year 2025 . In many countries, $\mathrm{T} 2 \mathrm{DM}$ is one of the most prevalent and fastest growing diseases (Gerstein \#\#008).

India has already become the "Diabetes Capital" of the world, with over 3 crore affected patients, which is only the tip of the iceberg (Shah,
2003). It is estimated that there are approximately 33 million adults with diabetes in India. This number is likely to increase to 57.2 million by the year 2025. In 2004, India had an estimated 37.76 million diabetics; 21.4 million in urban areas and 16.36 million in rural areas (ICMR, 2006; IDF, 2006). The Chennai Epidemiological Study found percentages with diabetic retinopathy, microalbuminurea and peripheral neuropathy to be $17.6 \%, 26.9 \%$ and $26.1 \%$, respectively (Rema

H2005). The progression to T2DM is not inevitable for those with prediabetes. The progression into diabetes mellitus from prediabetes is approximately $25 \%$ over three to five years (Nathan ., 2007).

The quality of life of T2DM patients, with chronic and severe hypoglycemia, is adversely affected. Characteristic symptoms of tiredness and lethargy can become severe and lead to a decrease in work performance. The most common acute complications are metabolic problems and infection (Davidson, 1991). The impacts of T2DM are considerable. As a lifelong disease, it increases morbidity and mortality. At the same time, the disease and its complications cause a heavy economic burden for diabetic patients, their families and society. A better understanding about the cause of predisposition of Indians to get T2DM is necessary for future planning of healthcare policy and delivery (Hoskote \& Joshi, 2008).

T2DM is often initially managed by increasing exercise and dietary modification; medications are typically needed as the disease progresses (ADA, 2008). Modern medicines, despite offering a variety of effective treatment options, can have several adverse effects (Kelly, 1995; Parving $\quad$ H 1992). From ancient times, various herbal preparations have been used in the treatment of diabetes. In recent years also, several researchers have studied the use of herbal and mineral formulations in the treatment of T2DM (Anas

\#H011; Arun and Nalini, 2002; Bhattacharya

\#7999; Bhaskaran \#1990; Halim \& Ali, 
2002; Khan \& Safdar, 2003; Trivedi

H7004) and have found encouraging results without any side effects. Therefore, in the present study the effect of an ayurvedic formulation on $i \quad$ (T2DM) patients has been studied. This ayurvedic formulation is a combination of 8 herbs and one herbo-mineral, which have (anti-diabetic properties) with (rejuvenator).

\section{METHODS}

The ayurvedic formulation use in the present study and the investigation procedure are described as follows.

\section{Components and Preparation of the} Ayurvedic Formulation (AF)

In the present study, an attempt has been made to clinically investigate the anti-diabetic activity of an in NIDDM patients. is a herbs and herbo-mineral formulation, comprising of 8 indigenous medicinal plants, namely Tinospora cordifolia (Giloya) stem, Gymnema sylvestre (Gudmar) leaves, Cinnamomum tamala (Tejpatt) leaves, Emblica officinalis (Amalki) fruit, Syzygium cumini (Jamun) seed, Trigonella foenum-graecum (Methi) seed, Curcuma longa (Haridra) rhizome HPicrorhiza kurroa (Katuki) rhizome $H$ and one herbo-mineral Asphaltum puniabiunum ( $o$ ) oozing ( $o$ ). These herbs and herbo-mineral are well known in the traditional Ayurveda system of medicine for their various therapeutic properties, especially hypoglycemic activity. Phytochemical and Pharmacological effects, and Properties ( $n)$ of selected herbs and herbomineral have been shown in Table (1) and Table (2), respectively.

$$
l
$$$$
\text { (pills) of }
$$

$$
\text { (adopted from }
$$

Sarangadhara Samhita, 2001): Solid extract pills were prepared from this Ayurvedic formulation. The (decoctions, infusions) of each herb and herbo-mineral was prepared separately. All these (decoctions, infusions) were next mixed in a container and boiled for preparation of $c \quad$ (solid extract). $c$ was prepared by boiling the coarsely powered drugs with specified quantity of water, till the volume reduced to $1 / 4^{\text {th }}$; then filtering and evaporated to dryness (CCRAS, 2005). The percentages of herbs and herbo-mineral used in the Ayurvedic formulation are shown in Table (3). 
Table (1): Phyto-chemicals present in the selected herbs and herbo-mineral of the Ayurvedic formulation and their Pharmacological effects.

\begin{tabular}{|c|c|c|c|}
\hline Plants & Phytochemicals & $\begin{array}{l}\text { Pharmacological } \\
\text { Effects }\end{array}$ & References \\
\hline $\begin{array}{r}\text { 1. Tinospora } \\
\text { cordifolia }\end{array}$ & $\begin{array}{l}\text { Tinosporin, palmatine, } \\
\text { tinocordiside, cordioside, bita- } \\
\text { sitosterol }\end{array}$ & $\begin{array}{l}\text { Antioxidant, antidiabetic, } \\
\text { antihyperlipidemic }\end{array}$ & $\begin{array}{l}\text { Gupta } \\
1967\end{array}$ \\
\hline $\begin{array}{l}\text { 2. Gymnena } \\
\text { sylvestre }\end{array}$ & $\begin{array}{l}\text { Gymnemic acid, sponins, } \\
\text { stigmasterol, trimethylamine, } \\
\text { quercitol, betaine, }\end{array}$ & $\begin{array}{l}\text { Antioxidant, antidiabetic, } \\
\text { antihyperlipidemic }\end{array}$ & $\begin{array}{l}\text { Bhaskaran } \\
1990\end{array}$ \\
\hline $\begin{array}{l}\text { 3. Emblica } \\
\text { officinalis }\end{array}$ & $\begin{array}{l}\text { Gallic acid, ellagic acid, phallantin, } \\
\text { phyllantidine, emblicanin A\&B }\end{array}$ & $\begin{array}{l}\text { Antioxidant, antidiabetic, } \\
\text { antihyperlipidemic, }\end{array}$ & $\begin{array}{c}\text { Bhattacharya } \\
\text { MH999 }\end{array}$ \\
\hline $\begin{array}{l}\text { 4. Curcuma } \\
\text { longa }\end{array}$ & $\begin{array}{l}\text { Curcumin, stigmastrol, } \alpha \& \beta \\
\text { turmerone, desmithoxy \& } \\
\text { bisdesmithoxy curcumin, }\end{array}$ & $\begin{array}{l}\text { Antidiabetic, antioxidant, } \\
\text { antihyperlipidemic }\end{array}$ & $\begin{array}{l}\text { Halim and Ali, } \\
2002\end{array}$ \\
\hline $\begin{array}{l}\text { 5. Syzygium } \\
\text { cumini }\end{array}$ & $\begin{array}{l}\text { Galic acid, glycolic acids, ellagic } \\
\text { acid, betulinic acid, bita-sitosterol }\end{array}$ & $\begin{array}{l}\text { Antidiabetic, antioxidant } \\
\text { antihyperlipidemic }\end{array}$ & $\begin{array}{l}\text { Prince } \\
2004\end{array}$ \\
\hline $\begin{array}{l}\text { 6. Cinnamomum } \\
\text { tamala }\end{array}$ & $\begin{array}{l}\text { Cinnamaldehyde, eugenol, geraniol, } \\
\text { cinnamic aldehyde, } \alpha \& \beta \text { pinenes }\end{array}$ & $\begin{array}{l}\text { Hypoglycemic activity, } \\
\text { antidiabetic. }\end{array}$ & $\begin{array}{lr}\text { Kar } & 2003 ; \\
\text { Saxena } & J \\
2006 & \\
\end{array}$ \\
\hline $\begin{array}{l}\text { 7. T. foenum- } \\
\text { graecum }\end{array}$ & $\begin{array}{l}p \\
\text { 4-hydroxyisoleucine }\end{array}$ & $\begin{array}{l}\text { Hypoglycemic activity, } \\
\text { Insulinotropic compound }\end{array}$ & $\begin{array}{l}\text { Shani } \quad \text { H } \\
\text { 1974; Narender } \\
\text { \#1006 }\end{array}$ \\
\hline $\begin{array}{l}\text { 8. Picrorhiza } \\
\text { kurroa }\end{array}$ & $\begin{array}{l}\text { Kutkins (kutkosides, picrosides), } \\
\text { kutkiol, kutkisterol, picrorrhizin. }\end{array}$ & $\begin{array}{l}\text { Hepatoprotective activity, } \\
\text { antioxidant, } \\
\text { anticholestatic }\end{array}$ & Joy $\quad$ HF999 \\
\hline $\begin{array}{l}\text { 9. Asphaltum } \\
\text { puniabiunum }\end{array}$ & $\begin{array}{l}\text { Benzoic acid, hippuric acid, fulvic } \\
\text { acids, humic acid, dibenzo-alpha- } \\
\text { pyrones }\end{array}$ & $\begin{array}{l}\text { Rasayana herb, } \\
\text { adaptogen, antidiabetic, } \\
\text { antioxidant, reduced } \\
\text { lipid peroxidation, }\end{array}$ & $\begin{array}{l}\text { Saxena } \quad \text { H } \\
\text { 2003; } \\
\text { Puri, 2006 }\end{array}$ \\
\hline
\end{tabular}


Table (2): Ayurvedic properties (Rasapanchakd) of selected herbs and herbo-mineral of the Ayurvedic formulation (Mishra \& Chunekar, 1995; Pandey 2004)

\begin{tabular}{|c|c|c|c|c|c|c|c|c|}
\hline $\begin{array}{l}\text { Selected } \\
\text { Herbs }\end{array}$ & $\begin{array}{l}\text { Parts } \\
\text { Used }\end{array}$ & $\begin{array}{l}\text { Rasa } \\
\text { (taste) }\end{array}$ & $\begin{array}{l}\text { Guna } \\
\text { (qualities) }\end{array}$ & $\begin{array}{l}\text { Veerya } \\
\text { (d ature) }\end{array}$ & Vipaka & Dosha-karma & $\begin{array}{l}\text { Roga- } \\
\text { ghnata }\end{array}$ & $\begin{array}{l}\text { Doses } \\
\text { in power }\end{array}$ \\
\hline$c$ & Stem & $\begin{array}{ll}p & H \\
g & \end{array}$ & $\begin{array}{ll}c & H \\
o & \end{array}$ & & $i$ & $p$ & $i^{l}$ & 3-6 gm \\
\hline \multirow[t]{2}{*}{$c$} & Leaf & $g \quad H$ & $h \quad H$ & & $g$ & $g \quad I$ & $\begin{array}{l}i \\
e\end{array}$ & B-6 gm \\
\hline & Fruit & $\begin{array}{ccc}H & \\
& H \\
& & H \\
H & \end{array}$ & $h$ & s peeta & $i$ & $p$ & $\oint_{i}^{l}$ & $3-6 \mathrm{gm}$ \\
\hline$p$ & Leaf & $g \quad H$ & $h \quad H$ & & $g$ & $g \quad I$ & $i$ & H-3 gm \\
\hline$d$ & Rhizome & $\begin{array}{l}p \\
g\end{array}$ & $\begin{array}{l}n \\
h \\
\end{array}$ & & $g$ & $p$ & 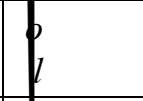 & $H 1-3 \mathrm{gm}$ \\
\hline$f$ & Seed & $\begin{array}{ll}g & H\end{array}$ & \begin{tabular}{|ll}
$h$ & $H$
\end{tabular} & $\phi$ & $g$ & $l \quad I$ & $i$ & $1-3 \mathrm{gm}$ \\
\hline$i$ & Seed & $p \quad H g$ & $\begin{array}{c}h \\
o\end{array}$ & 4 & $g$ & $I$ & $l$ & 3-6 gm \\
\hline$g$ & Rhizome & $p$ & $\begin{array}{cc}h & H \\
n & \end{array}$ & $o$ & $g$ & $g \quad I l$ & $l$ & 1-3 gm \\
\hline$O$ & $\begin{array}{l}o \\
\text { (oozing) }\end{array}$ & $\begin{array}{l}p \quad H g \\
g\end{array}$ & $\begin{array}{ll}h & H\end{array}$ & $o$ & $g$ & $p$ & $i^{i}$ & $\begin{array}{l}250-500 \\
\mathrm{mg}\end{array}$ \\
\hline
\end{tabular}

Table (3): Percentages of herbs and herbo-mineral in the Ayurvedic formulation

\begin{tabular}{|c|c|c|c|c|}
\hline Common Name & $\begin{array}{l}\text { Botanical } \\
\text { Name }\end{array}$ & $\begin{array}{c}\text { Collected Part } \\
\text { Used }\end{array}$ & $\begin{array}{l}\text { Percent } \\
(\%)\end{array}$ & $\begin{array}{l}\text { Wt. of each in } \\
\text { Vati (in mg) }\end{array}$ \\
\hline \multicolumn{5}{|c|}{ Herbs } \\
\hline$c$ & T. cordifolia & Stem & $15 \%$ & 60 \\
\hline$c$ & G. sylvestre & Leaves & $15 \%$ & 60 \\
\hline$f$ & S. cumini & Seeds & $15 \%$ & 60 \\
\hline \multirow[t]{2}{*}{$i$} & T. foenum-graecum & Seeds & $15 \%$ & 60 \\
\hline & E. officinalis & Fruit & $10 \%$ & 40 \\
\hline$p$ & C. tamala & Leaves & $10 \%$ & 40 \\
\hline$d$ & C. longa & Rhizome & $5 \%$ & 20 \\
\hline$g$ & P. kurroa & Rhizome & $5 \%$ & 20 \\
\hline \multicolumn{5}{|c|}{$d \quad I$} \\
\hline \multirow[t]{2}{*}{$o$} & A. puniabiunum & Purified Extract & $10 \%$ & 40 \\
\hline & & Total & $100 \%$ & $400 \mathrm{mg}$ \\
\hline
\end{tabular}


The prepared from the extract of

was tested according to Central Council for Research in Ayurveda and Siddha (CCRAS, 2005) and the analytical specifications are given in Table (4).

Table (4): Analytical data (Specifications) of the Ghansatt Vati prepared from the extract of the Ayurvedic formulation

\begin{tabular}{|c|c|c|}
\hline \multicolumn{2}{|c|}{ Tests } & Result \\
\hline & Colour & Blackish brown \\
\hline & Odour & Soft and Cow urine smell \\
\hline & Taste & $\begin{array}{lc}p & \text { (bitter) and } \\
g & \text { (astringent) }\end{array}$ \\
\hline \multicolumn{2}{|l|}{$\mathrm{pH}$} & 7.5 \\
\hline \multicolumn{2}{|l|}{ Loss of drying at $105^{\circ} \mathrm{C}$} & $2.03 \% \mathrm{w} / \mathrm{w}$ \\
\hline \multicolumn{2}{|l|}{ Hardness of vati } & $2.75 \mathrm{~kg} / \mathrm{cm}^{2}$ \\
\hline \multicolumn{2}{|c|}{ Uniformity of weight } & $405 \mathrm{mg}$ \\
\hline \multicolumn{2}{|c|}{ Time for dissolution/disintegration of the vati } & 12 minutes \\
\hline \multicolumn{2}{|c|}{$\%$ of water soluble extract } & $45.2 \% \mathrm{w} / \mathrm{w}$ \\
\hline
\end{tabular}

\section{Study Procedure}

This clinical study was carried out on 15 patients of T2DM, including 10 males (66.7\%) and 5 females (33.3\%), who satisfied the selection criteria (given below). The age and sex distribution of the selected patients are given in Table 5. The M (T2DM or NIDDM) patients were selected randomly from the out-patient department (OPD) of the Department of Human Consciousness and Yogic Sciences, Dev Sanskriti
Vishwavidyalaya and Clinic of Brahmavarchas Research Institute, Shantikunj, Haridwar (Uttarakhand). These patients were suffering from T2DM for 2 to 3 years. It was made sure that the selected patients were not suffering from any complications. Before this study, the patients had been taking as usual treatment. However, during the course of the present study, the patients did not take any other medication for T2DM besides ayurvedic formulation.

Table (5): Age and sex distribution of 15 T2DM patients selected for this study.

\begin{tabular}{|l|c|c|c|}
\hline Category & $\mathbf{4 0 - 4 9} \mathbf{y r s}$ & $\mathbf{5 0 - 5 9} \mathbf{y r s}$ & $\mathbf{6 0 - 7 0}$ yrs \\
\hline Type $2 \mathrm{DM}$ & Male: 05 & Male: 03 & Male: 02 \\
& Female: 03 & Female: 01 & Female: 01 \\
\hline
\end{tabular}

\section{Research Design}

'Single Group Design' was adopted for the research design. Before and after intervention, diabetes diagnostic tests of sugar level (blood and urine tests) were administered for collection of Pre-test and Post-test data. 


\section{Sampling}

In the present study accidental sampling was adopted for the selection of samples.

\section{Tools and Methods Adopted for Pathological Tests}

(1). RA 50 Analyzer was used for measuring Fasting Blood Sugar (FBS) and Post Patrum Blood Sugar (PPBS). Blood sugar estimation was done by GOD/POD Method (Trinder, 1969).

(2). Glycocylated Hemoglobin (HbA1C) was evaluated through Bio-Rad D10 Hemoglobin Testing Analyzer by Chromatographic Method based HPLC assay (Hadjadj, 2005).

(3). Urine test for sugar fasting was done by Dipsticks Method.

Other physical and supporting parameters such as weight, height, Pulse Rate, Blood Pressure, Serum Cholesterol, Serum Triglyceride, Blood Urea, Hemoglobin, Serum Bilirubin, etc. were also monitored to make sure that there were no complications involved in these patients. The measurements showed that the values of Serum Cholesterol, Serum Triglyceride, Blood Urea, Hemoglobin and Serum Bilirubin were within normal limits and the patients did not suffer from any complications.

\section{Criteria of Selection of T2DM Patients}

Those diabetes patients were selected who had: (i) Clinical symptoms of diabetes, (ii) FBS $\geq 126$ $\mathrm{mg} / \mathrm{dl}$ (Fasting: zero calorie for $8 \mathrm{hr}$ ), (iii) PPBS $\geq$ $200 \mathrm{mg} / \mathrm{dl}$, (iv) $\mathrm{HbAlC}>7 \%$, and (v) Urine Sugar Fasting was positive.

\section{Exclusion Criteria for this Study}

Insulin dependent diabetes mellitus (IDDM), Secondary or complications diabetes mellitus, CVS (Cardio Vascular Diseases), Severe Illness, Hypertension (moderate and severe) BP $\geq 150 / 90$, Age less than 40 years and greater than 70 years, Pregnant Women, BMI $<18$ and $>40$.

Above diagnostic criteria were chosen based on the recommended guidelines of three common standards, i.e. WHO (1999), IDF (2005) and ADA (2006).

\section{Intervention}

The 15 T2DM patients selected for this study were given solid extract (prepared from

formulation) at a dose of two vati (each vati of 400 $\mathrm{mg}$ ), twice a day, with lukewarm water, before taking morning and evening meals (empty stomach), for twelve months duration. Besides this, the patients were suggested to walk 1 to $3 \mathrm{~km}$ daily in the morning and follow the Diet Chart given in Table 6. The patients did not take any other medication for T2DM during the course of the study. 
Table (6): Diet Chart suggested to the 15 T2DM patients selected for this study (calorific vegetarian diet: 1400-1600 calories)

\begin{tabular}{|l|l|l|l|}
\hline S.No. & \multicolumn{1}{|c|}{ Time } & & \multicolumn{1}{c|}{ Suggested Food } \\
\hline 1 & $7-8$ a.m. & Breakfast & $\begin{array}{l}\text { 25 gm Sprouted Seeds + 100 ml Vegetable Soup } \\
\text { or, 200 ml Skimmed Milk without sugar } \\
+5 \text { Marigold Biscuit }\end{array}$ \\
\hline 2 & $\begin{array}{l}11 \text { a.m.- } 12 \\
\text { noon }\end{array}$ & Lunch & $\begin{array}{l}\text { Chapati + Dal + Green Vegetable + Salad } \\
+200 \mathrm{ml} \text { Butter Milk }\end{array}$ \\
\hline 3 & $4-5$ p.m. & $\begin{array}{l}\text { Evening } \\
\text { Snacks }\end{array}$ & $\begin{array}{l}\text { Seasonal Fruits (Orange, Guava, Apple etc.) } \\
\text { or, } 100 \text { ml Vegetable Soup (Carrot, Tomato, } \\
\text { Lauki, Parwal etc.) } \\
\text { or, 50 gm Roasted Bengal Gram }\end{array}$ \\
\hline 4 & $8-9$ p.m. & Dinner & $\begin{array}{l}\text { Daliya (cracked wheat) or, Chapati } \\
+ \text { Dal + Vegetable }\end{array}$ \\
\hline 5 & 10 p.m. & Night & 250 ml Skimmed Milk \\
\hline
\end{tabular}

Note: Sunflower Oil or Soyabean Oil or Mustard Oil (25 gm) should be used for cooking (approximately 60 calorie). Sweets, carbohydrates (rice, curd, potato etc.) and oily foods must be avoided.

The prepared ayurvedic formulation extract vati was given to the $15 \mathrm{~T} 2 \mathrm{DM}$ patients, for one year. Diabetic diagnostic parameters of these patients, i.e. FBS, PPBS, HbA1C and Urine Sugar Fasting were monitored every three months. The pre test and the post test results were compared and the effectiveness of the Ayurvedic formulation in reducing blood and urine glucose level was analyzed.

\section{Statistical Analysis}

After collection and scoring of research data, the raw scores were converted into t-scores. For statistical analysis, paired t-test was used to measure the significant difference between the means of Pre-test and Post-test.

\section{RESULTS}

\section{Signs and Symptoms of the T2DM Patients}

The clinical signs and symptoms of the selected 15 T2DM patients were measured both before and after the study. Table 7 lists the number of patients that showed these signs and symptoms. It can be seen from Table 7 that there was significant improvement in the clinical features. Patients reported improvement in frequency of urine, which was reduced. Polyphagia, nocturia and unquenched thirst were subsided and general feeling of well being was reported by all the patients; Burning sensations in hands or soles, pain/cramps and weakness were subsided. 
Table (7): Number of T2DM patients that showed the clinical signs and symptoms measured in the present study, both before and after the study period.

\begin{tabular}{|c|c|c|c|c|}
\hline $\begin{array}{l}\text { Signs and Symptoms } \\
\qquad(\mathrm{n}=15)\end{array}$ & $\begin{array}{l}40-49 \\
\text { years }\end{array}$ & $\begin{array}{l}50-59 \\
\text { years }\end{array}$ & $\begin{array}{l}60-70 \\
\text { years }\end{array}$ & $\begin{array}{l}\text { Improvement } \\
\text { in (\%) }\end{array}$ \\
\hline & Before $\mid$ After & Before $\mid$ After & Before $\mid$ After & \\
\hline Polyuria (frequent urination) & \begin{tabular}{l|l}
8 & 0
\end{tabular} & \begin{tabular}{l|l}
4 & 1
\end{tabular} & \begin{tabular}{l|l}
3 & 1
\end{tabular} & 86 \\
\hline Polydipsia (increased thirst) & $8 \mid 0$ & \begin{tabular}{l|l}
4 & 0
\end{tabular} & \begin{tabular}{l|l}
3 & 1
\end{tabular} & 95 \\
\hline Polyphagia (increased hunger) & \begin{tabular}{l|l}
8 & 0
\end{tabular} & \begin{tabular}{l|l}
4 & 0
\end{tabular} & \begin{tabular}{l|l}
3 & 1
\end{tabular} & 95 \\
\hline General weakness & $8 \mid 0$ & \begin{tabular}{l|l}
4 & 0
\end{tabular} & 31 & 96 \\
\hline Burning sensation in hands/soles & $6 \mid 0$ & $3 \mid 0$ & 31 & 92 \\
\hline Loss of weight & $2 \mid 0$ & \begin{tabular}{l|l}
1 & 0
\end{tabular} & 21 & 80 \\
\hline Pain or cramps & \begin{tabular}{l|l}
5 & 0
\end{tabular} & $3 \mid 0$ & \begin{tabular}{l|l}
2 & 1
\end{tabular} & 90 \\
\hline
\end{tabular}

\section{Diabetic Parameters of the T2DM Patients}

The Pre test and Post test values of the diabetic parameters, i.e. FBS, PPBS, $\mathrm{HbA} 1 \mathrm{C}$ and Urine Fasting Sugar were measured for the T2DM patients.

Figure (1) gives the mean FBS values for the T2DM patients at the beginning of the study and after every 3 months. The horizontal lines in Fig. 1 depict the standard ranges of FBS values, i.e. patients that test positive for T2DM have FBS $\geq$ $126 \mathrm{mg} / \mathrm{dl}$, while normal individuals have FBS value between $70-110 \mathrm{mg} / \mathrm{dl}$. It can be seen from Fig. 1 that the mean FBS value of the patients at the beginning of the study was $153.47 \mathrm{mg} / \mathrm{dl}$, and it decreased almost linearly during the course of the study. At the end of the study period, the mean FBS value was $103.6 \mathrm{mg} / \mathrm{dl}$, which is within the range of FBS values for normal individuals.

Table (8) gives the mean Pre and Post FBS values as well as the statistical analysis data for the T2DM patients. The correlation is 0.91. The obtained t-value is 35.53 , which is significant at 0.001 level of confidence. This shows that the
Ayurvedic formulation lead to a significant reduction in the mean FBS values of the T2DM patients.

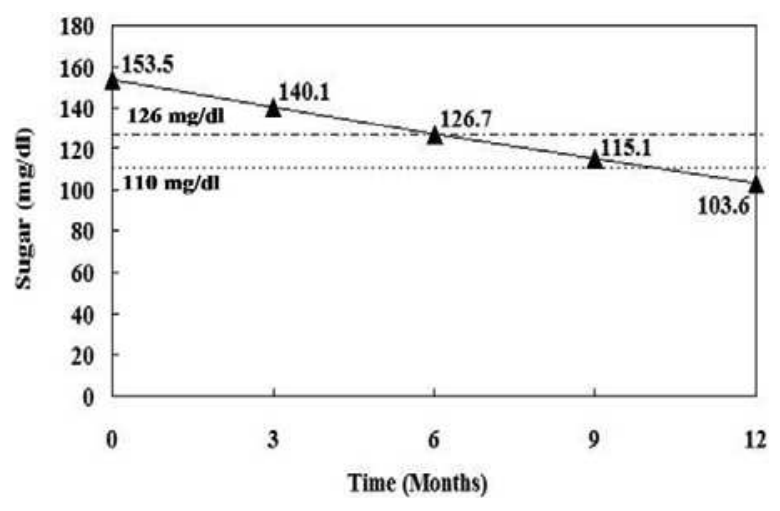

Fig. (1): The mean FBS values for the T2DM patients at the beginning of the study and after every 3 months. The horizontal lines depict the standard ranges of FBS values, i.e. patients that test positive for T2DM have FBS $\geq 126 \mathrm{mg} / \mathrm{dl}$, while normal individuals have FBS value between $70-110 \mathrm{mg} / \mathrm{dl}$. 
Table (8): The mean Pre and Post FBS values of the T2DM patients and the corresponding statistical analysis data.

\begin{tabular}{|c|c|c|c|c|c|c|c|}
\hline Group & $\mathbf{N}$ & $\begin{array}{c}\text { Mean } \\
(\mathbf{m g} / \mathrm{dl})\end{array}$ & SD & SED & $\mathbf{r}$ & $\mathbf{t}$ - value & Level of significance \\
\hline FBS Pre & 15 & 153.47 & 12.79 & \multirow{2}{*}{5.43} & 0.91 & 35.53 & $\begin{array}{c}0.001 \\
(\mathrm{df}=14)\end{array}$ \\
\hline FBS Post & 15 & 103.60 & 12.74 & &
\end{tabular}

Figure (2) gives the mean PPBS values for the T2DM patients at the beginning of the study and after every 3 months. The horizontal lines in Fig. 2 depict the standard ranges of PPBS values, i.e. patients that test positive for T2DM have PPBS $\geq$ $200 \mathrm{mg} / \mathrm{dl}$, those with PPBS below $180 \mathrm{mg} / \mathrm{dl}$ are considered controllable, while normal individuals have PPBS value below $140 \mathrm{mg} / \mathrm{dl}$. It can be seen from Fig. 2 that the mean PPBS value of the patients at the beginning of the study was 251.0 $\mathrm{mg} / \mathrm{dl}$, and it decreased almost linearly during the course of the study. At the end of the study period, the mean PPBS value was $175.0 \mathrm{mg} / \mathrm{dl}$, which is within the controllable range of PPBS values.

Table (9) gives the mean Pre and Post PPBS values as well as the statistical analysis data for the T2DM patients. The correlation is 0.88 . The obtained t-value is 30.19 , which is significant at 0.001 level of confidence. This shows that the Ayurvedic formulation lead to a significant reduction in the mean PPBS values of the T2DM patients.

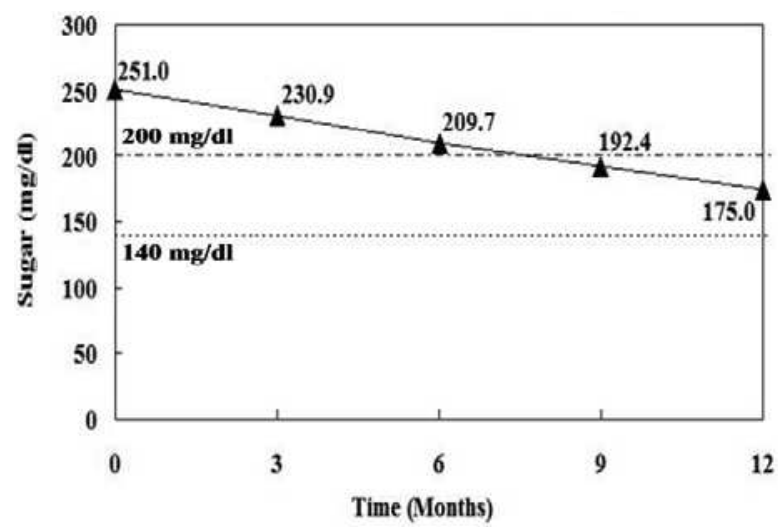

Fig. (2): The mean PPBS values for the T2DM patients at the beginning of the study and after every 3 months. The horizontal lines depict the standard ranges of PPBS values, i.e. patients that test positive for T2DM have PPBS $\geq 200 \mathrm{mg} / \mathrm{dl}$, while normal individuals have PPBS value $<140$ $\mathrm{mg} / \mathrm{dl}$.

Table (9): The mean Pre and Post PPBS values of the T2DM patients and the corresponding statistical analysis data.

\begin{tabular}{|c|c|c|c|c|c|c|c|}
\hline Group & $\mathbf{N}$ & $\begin{array}{c}\text { Mean } \\
(\mathbf{m g} / \mathbf{d l} \mathbf{l})\end{array}$ & SD & SED & $\mathbf{r}$ & $\mathbf{t}$ - value & $\begin{array}{c}\text { Level of } \\
\text { significance }\end{array}$ \\
\hline PPBS Pre & 15 & 251.00 & 18.48 & & & & 0.001 \\
PPBS Post & 15 & 175.6 & 20.11 & 9.66 & 0.88 & 30.19 & $(\mathrm{df}=14)$ \\
\hline
\end{tabular}


Figure (3) gives the mean $\mathrm{HbA1C}$ values for the T2DM patients at the beginning of the study and after every 3 months. The horizontal lines in Fig. 3 depict the standard ranges of $\mathrm{HbA1C}$ values, i.e. patients that test positive for T2DM have $\mathrm{HbA} 1 \mathrm{C} \geq 7 \%$, and those with $\mathrm{HbA} 1 \mathrm{C}$ below $7 \%$ are considered controllable, while normal individuals have $\mathrm{HbA} 1 \mathrm{C}$ value less than $6.4 \%$. It can be seen from Fig. 3 that the mean $\mathrm{HbAlC}$ value of the patients at the beginning of the study was $7.53 \%$, and it decreased almost linearly during the course of the study. At the end of the study period, the mean $\mathrm{HbA} 1 \mathrm{C}$ value was $6.48 \% \mathrm{mg} / \mathrm{dl}$, which is within the controllable range of $\mathrm{HbAlC}$ values.

Table (10) gives the mean Pre and Post $\mathrm{HbA1C}$ values as well as the statistical analysis data for the T2DM patients. The correlation is 0.83 . The obtained t-value is 16.41 , which is significant at 0.001 level of confidence. This shows that the Ayurvedic formulation lead to a significant reduction in the mean $\mathrm{HbA1C}$ values of the T2DM patients.

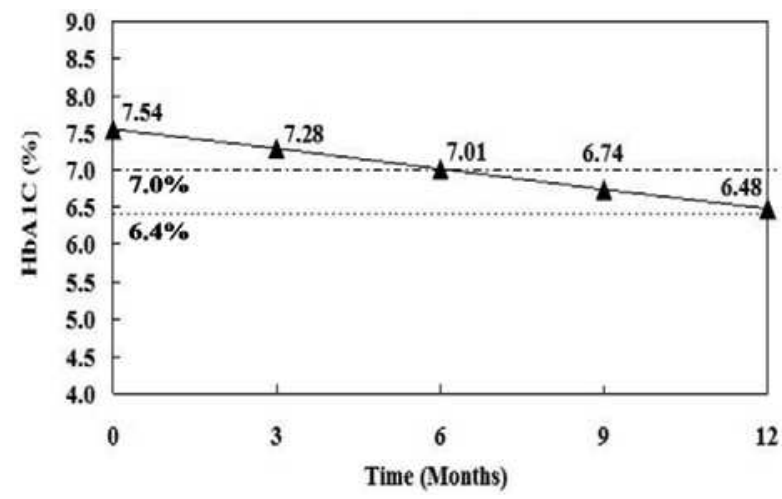

Fig. (3): The mean $\mathrm{HbA1C}$ values for the T2DM patients at the beginning of the study and after every 3 months. The horizontal lines depict the standard ranges of $\mathrm{HbA1C}$ values, i.e. patients that test positive for T2DM have $\mathrm{HbA} 1 \mathrm{C} \geq 7.0 \%$, while normal individuals have $\mathrm{HbA1C}$ value less than $6.4 \%$.

Table (10): The mean Pre and Post HbA1C values of the T2DM patients and the corresponding statistical analysis data.

\begin{tabular}{|c|c|c|c|c|c|c|c|}
\hline Group & $\mathbf{N}$ & $\begin{array}{c}\text { Mean } \\
(\%)\end{array}$ & SD & SED & $\mathbf{r}$ & $\mathbf{t}$ - value & Level of Significance \\
\cline { 1 - 5 } HbA1c Pre & 15 & 7.53 & 0.43 & \multirow{2}{*}{0.25} & 0.83 & 16.41 & $\begin{array}{c}0.001 \\
(\mathrm{df}=14)\end{array}$ \\
\cline { 1 - 6 } HbA1c Post & 15 & 6.48 & 0.42 & & & & \\
\hline
\end{tabular}

Thus, Ayurvedic formulation leads to an overall significant reduction in blood glucose levels in T2DM patients. This study suggests that the Ayurvedic formulation had reasonably favorable hypoglycemic effects proved by clinical improvement and bio-chemical analysis.

The Urine Sugar is positive for T2DM patients and if the value of Urine Sugar Fasting is 'nil' for an individual, it is considered normal. In the present study the Pre
Urine Sugar Fasting values for the T2DM patients ranged from +1 to +3 . After one year of Ayurvedic formulation treatment, the Urine Sugar Fasting value became 'nil', i.e. normal value, for 9 out of the 15 patients. Another 3 patients had 'trace' Urine Sugar Fasting and only 3 patients tested positive, i.e. +1 value for Urine Sugar Fasting. This shows that Ayurvedic formulation had a significant impact in reducing the Urine Sugar Fasting values in T2DM patients. 


\section{DISCUSSION}

Diabetic care needs patience, compassion and optimism from the physician. Patient must be actively involved in his own management and should develop confidence to bring about adjustment in day to day life management. The herbs and herbo-mineral based Ayurvedic formulation used in this study was prepared based on traditional knowledge of the Ayurvedic system of medicine, recent clinical studies and pharmacology. All the herbs and herbo-mineral used in this formulation have independent hypoglycemic activity, as established through various research studies.

The improvement in clinical features of this open clinical study has been summarized in Table (7). All the patients experienced symptomatic improvement. Patients reported improvement in frequency of urine, which was reduced. Nocturia and unquenched thirst were subsided and the general feeling of well being was reported by all the patients; polyphagia and weakness were subsided.

Measurement of the blood glucose parameters showed that the initial mean FBS value of 153.47 $\mathrm{mg} / \mathrm{dl}$ and mean PPBS value of $251 \mathrm{mg} / \mathrm{dl}$, reduced to normal and controllable values of $103.60 \mathrm{mg} / \mathrm{dl}$ (mean FBS) and $175.65 \mathrm{mg} / \mathrm{dl}$ (mean PPBS), respectively. The linear reduction was observed in FBS and PPBS values during the study period. In addition, there was significant reduction of mean $\mathrm{HbA} 1 \mathrm{C}$ value also, which reduced from $7.53 \%$ to $6.48 \%$, which is within the controllable range. The Urine Sugar Fasting values were also reduced significantly for the T2DM patients during the study period. It is noteworthy that not only the mean values, but the individual values of the blood and urine glucose levels for each one of the 15 patients also decreased continuously during the course of the study. These observations confirmed the hypoglycemic effect of the herbs and herbomineral based Ayurvedic formulation, which lead to a significant reduction in blood and urine sugar parameters in T2DM patients who completed the clinical trial successfully. No side effects were noticed during the study period.

The possible mechanism for the hypoglycemic activity of the Ayurvedic formulation used in the present study may be the stimulation / regeneration effect on beta cells, promotion of insulin secretion and reduction of insulin resistance. The decrease in the elevated blood glucose level of T2DM patients caused by the Ayurvedic formulation may be attributed to its ingredients such as $c$ stem, which has anti-diabetic properties (Nadkarni, 1976) and hypoglycemic activity (Sivakumar \& Mohamed, 2009); leaf of $c$, which performs several significant functions, i.e. suppressing blood glucose, insulinotropic effect and promoting insulin secretion (Ogawa B2004); $f$ seed, which has shown significant hypoglycemic action in both urine and blood glucose (Ravi BH 2004); fruit, which exhibits hypoglycemic, hypolipiadaemic action (Sharma, 2002); $p$ leaf, which exhibits antihypercholesterolemic and antihypertriglyceridemic effects (Kar \# \#003); and also C. tamala ( $p \quad$ ) leaves extract induce antihyperglycemic as well as antioxidant activities in STZ-diabetic rats (Chakravarty and Das, 2010); $d$ rhizome extracts, which have shown hypoglycemic effect, hypocholesterolemic effect and blood glucose lowering activity in diabetic rats (Arun and Nalini, 2002); Methi seed, which acts as a hypoglycemic and anti-inflammatory agent (Daniel and Maria, 2000); rhizome of $g$, which has hepatoprotective and anti-diabetic activity, is a proven hypoglycemic agent and has $l \quad$ properties (Mishra, 1995); and, Shilajit (A. puniabiunum), a herb, reduces insulin resistance in T2DM patients (Puri, 2006).

After studying the above mentioned observations from the open literature, these herbs and herbo-mineral were selected for the present 
study and the proposed Ayurvedic formulation was prepared. The results of the present study confirm the curative effect of these herbs and herbomineral, when given in combined form to T2DM patients.

\section{Conclusion}

In the present study, an Ayurvedic formulation was prepared from 8 herbs and one herbo-mineral. It was prescribed to 15 Type II Diabetes Mellitus (T2DM) patients, for one year along with dietary recommendations. Diabetic diagnostic parameters of these patients, i.e. FBS, PPBS, HbA1C and Urine Sugar Fasting were monitored every three months. The pre-test and the post-test results were compared and the effectiveness of the Ayurvedic formulation in reducing blood and urine glucose level was analyzed.

It was found that Ayurvedic formulation was significantly effective in reducing the blood and urine sugar level in T2DM patients. After one year of treatment, the mean FBS value became normal and the mean PPBS and mean $\mathrm{HbA1C}$ values came within the controllable range. The patients showed significant improvement in clinical and biochemical investigations. The test drug did not display any side effects. Thus, it can be concluded that the Ayurvedic formulation used in the present study may be used as an effective antihyperglycemic agent for T2DM patients.

DEVASHISH BHARDWAJ, BAMS, Research Scholar, Dev Sanskriti Vishwavidyalaya, Haridwar, India; VEENIT K. AGNIHOTRI, MD, PhD, Reader \& Head, Department of Swasthavritta, Rishikul State P.G. Ayurvedic College \& Hospital, Haridwar, India; PRANAV PANDYA, MD, Chancellor, Dev Sanskriti Vishwavidyalaya, Haridwar, India.

\section{REFERENCES}

American Diabetes Association (2006) Diagnosis and classification of diabetes mellitus. 43-48.

$\begin{array}{ccc}\text { American Diabetes Association (2008) } & p \\ l & l \quad I \quad & J\end{array}$ http://www.diabetes.org/diabetesstatistics/prevalence.jsp/ Retrieved on 17 March 2006.

Anas, M., Mohsin, M., Siddiqui, M. \& Mannan, A. (2011) Therapeutic evaluation of a polyherbal formulation in type 2 diabetes mellitus. $e$

$$
\begin{array}{lll}
p & g & \text { HIO(4), 711-715. }
\end{array}
$$

Arun, N. \& Nalini, N. (2002) Efficacy of turmeric on blood sugar and polyol pathway in diabetic albino rats.

$$
\begin{array}{lllll}
l & b & d & j & \boldsymbol{B} 7(1), 41-52 .
\end{array}
$$

Bhaskaran, K. M., Ahamath, B. K., Shanmugasundaram, K. R. \& Shanmugasundaram, E. R. (1990) Anti-diabetic effects of a leaf extract from Gymnena sylvestre in NIDDM patients. $f$

$$
\text { a BO, } 295 .
$$

Bhattacharya, A., Chatterjee, A., Ghosal, S. \& Bhattacharya, S.K. (1999) Antioxidant activity of active tannoid principle of Emblica officinalis. $e$

$$
\begin{array}{lll}
f & a & \text { B5, } 297 .
\end{array}
$$

Boon, N.A., Colledge, N. R. \& Walker, B. R. (2006) V

DNL a AJondon: Elsevier P. 805-847

Central Council for Research in Ayurveda and Siddha (2005) Data base on Medicinal Plants used in Ayurveda (vol.1). New Delhi: CCRAS.

Chakraborty, U. \& Das, H. (2010) Antidiabetic and Antioxidant Activities of Cinnamomum tamala Leaf Extracts in Stz-Treated Diabetic Rats. $c \quad f$

$$
B \quad \boldsymbol{E}(1), 12-18 .
$$

Daniel, Z. \& Maria, H. (2000)

$k$ D $\quad \mathbb{N}$ (Dey York, NY: Oxford

University Press, p.122.

Davidson, M.B. (1991) $i \quad V$

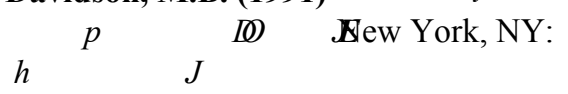

Gerstein, H. C., Miller, M. E., Byington, R. P., Goff, D. C., Bigger, J. T. \& Buse, J. B. (2008) Effects of intensive glucose lowering in type 2 diabetes. $j$ $\begin{array}{lll}a & i & \end{array}$

Gupta, S.S., Verma, S. C., Garg, V.P. \& Rai, M. (1967) Anti-diabetic effects of Tinospora cordifolia. 
Hadjadj, S. (2005) Test: Hemoglobin A1C. $i \quad$ B1 $B 900-294$

Halim, E. M. \& Ali, H. (2002) Hypoglycemic, hypolipidemic and antioxidant properties of combination of curcumin from Curcuma longa, Linn, and partially purified product from Abroma augusta, Linn. In streptozotocin induced diabetes $H e$

$$
\text { HI7, } 33 .
$$

Hoskote, S. S. \& Joshi, S. R. (2008) Are Indians Destined to be Diabetic? $f$

$$
l \quad e \quad, 56,225-226 \text {. }
$$

Indian council of Medical Research (2006)

$$
\text { j J }
$$

ICMR. http://www.icmr.nic.in/annual/2009-

10/english/ncd.pdf / 22 November 2012.

International Diabetes Federation (2006)

(D) a $\mathbf{A B r u s s e l s : ~ I n t e r n a t i o n a l ~ D i a b e t e s ~}$

Federation. Available at

http://www.eatlas.idf.org/media/ 8 September 2008.

International Diabetes Federation (2005) $c$

$$
N \quad \text { Brussels: International }
$$

Diabetes Federation.

Joy, K. L. \& Kuttan, R. (1999) Anti-diabetic Activity of Picrorrhiza kurroa extract.

$$
f \quad a \quad \text { IG7(2), 143-148. }
$$

Kar, A., Choudhary, B. K. \& Bandyopadhyay, N. G. (2003) Comparative evaluation of hypoglycaemic activity of some Indian medicinal plants in alloxan diabetic rats. $f$ $a$ 84(1), 105-108.

Kelly, D. E. (1995) Effects of weight loss on glucose homeostasis in NIDDM. $n \quad, 3,366-377$.

Khan, A. \& Safdar, M. (2003) Cinnamon improves glucose and lipids of people with type 2 diabetes $J$

26 B215-3218.

Mishra, B. \& Chunekar, K. C. (Ed.) (1995) $o$ $l \quad j \quad$ DML AVaranasi: Chaukhambha Bharti Academy.

\section{Nadkarni, K. M. \& Nadkarni, A. K. (1976) $e$ $\begin{array}{llll}i & i & \text { D } & \text { Mumbai: Popular Prakasan }\end{array}$ Pvt. Ltd.}

Narender, T., Puri, A., Saxena, R., Bhatia, G. \& Chandra, R. (2006) 4-hydroxyisoleucine an unusual amino acid as antidyslipidemic and antihyperglycemic agent. 293-296.
Nathan, D. M., Davidson, M. B., DeFronzo, R. A., Heine, R. J., Henry, R. R., Pratley, R. \& Zinman, B. (2007) Impaired fasting glucose and impaired glucose tolerance: implications for care. 30(3), 753-759.

Ogawa, Y. (2004) Gymnema sylvestre leaf extract: a 52-week dietary toxicity study in Wistar rats. $o$

$$
\begin{aligned}
& \text { M5(1), 8-18. } \\
& \text { Pandey, G. (Ed.) (2004) } \\
& \quad l \quad \text { DN EVaranasi: } \\
& \text { Chaukhambha Bharti Academy. }
\end{aligned}
$$

Parving, H. H., Gall, M. A., Skott, P., Jorgensen, H. E., Lokkegaard, H., Jorgensen, F., Nielsen, B. \& Larsen, S. (1992) Prevalence and causes of albuminuria in NIDDM patients. $g \quad e \quad$ H1(4), 758762.

Prince, P. S., Kamalakkannan, N. \& Menon, V. P. (2004) Antidiabetic and antihyperlipidemic effect of alcoholic Syzigium cumini seeds in alloxan induced diabetic albino rats. $f \quad a$ H1 $H$ 209.

Puri, H. S. (2006)

Delhi: India Book House.

Rema, M., Premkumar, S., Anitha, B., Deepa, R., Pradeepa, R. \& Mohan, V. (2005) Prevalence of diabetic retinopathy in Urban India: the Chennai Urban Rural Epidemiological Study (CURES) eye study. $\begin{array}{lllll}e & k & B & o & H 6\end{array}$ 22328-33.

Saxena, A. M., Mukherjee, S. K. \& Shukla, G. (2006) $l \quad e \quad N L$ New Delhi: National Institute of Science and Communication.

Saxena, N., Dwivedi, U. N., Singh, R.K., Kumar, A., Saxena, C., Saxena, R.C. \& Saxena, M. (2003) Modulation of oxidative and antioxidative status in diabetes by Asphaltum panjabinum. B6 $H$ 2469-2470.

Shah, S. N. (ed.) (2003) le $p \quad i$

IS AlMumbai: API

Shani, J., Goldsehmied, A., Joseph, B., Ahronson, Z. \& Sulman, F. G. (1974) Hypoglycaemie effect of Trigonella foenum graecum seeds and their major alkaloids in alloxan diabetic and normal rats $J$

$$
\begin{array}{llll}
e & l & p & \text { H10, 27-37. }
\end{array}
$$

Sharma P. V. (ed.) (2001) $o$ IR Ja Earanasi: Chaukhambha Publications. 
$\begin{array}{llllll}\text { Sharma, P. V. (1983) } & & & o & & \\ \text { Varanasi: } & k & & J & & \end{array}$

Sharma, P.V. (2002)

Varanasi: Chaukhamba Publications, p. 327.

Shastri, A. D. (1995) $o \quad$ o $\quad$ ID $\quad$ a

Varanasi: Chaukhambha Publications, p. 251-252.

Shukla, V.D., \& Tripathi, R. D. (Ed.) (2002)

$o$. Delhi : Chaukhamba Sanskrit Pratishthana.

Sulman, F. G. \& Menczel, E. (1962) Harokeach Haire (9:6). SH1308e.

Trider, P. A. (1969) Glucose was determined by using the enzymatic method (GOD-POD).

$$
\text { It, 24-33. }
$$

Trivedi, N. A., Mazumdar, B., Bhatt, J. D. \&

Hemavathi, K. G. (2004) Effect of shilajit on blood glucose and lipid profile in alloxan induced diabetic rats. $e$ $f$ $l$

\$6(6), 373-376.

World Health Organization (1999) $H$

$$
\text { DD Mreneva: WHO }
$$

$O$

$H$

$i$

(Sushrut Samhita Nidan, 6/27)

$p$

(Charak Samhita Sutrastana, 17/80) 